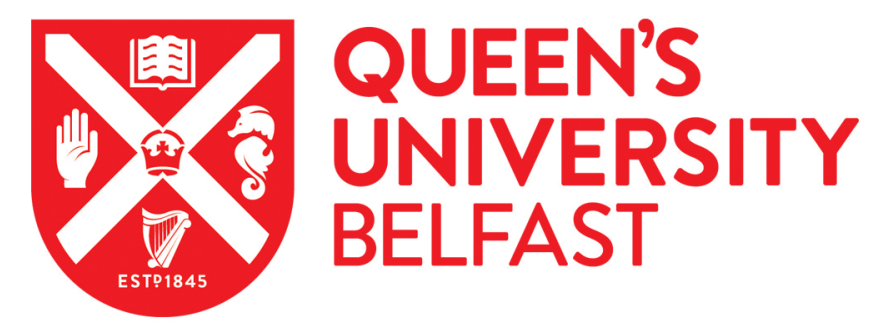

\title{
Biogeography, macroecology and species' traits mediate competitive interactions in the order Lagomorpha
}

Leach, K., Montgomery, W. I., \& Reid, N. (2015). Biogeography, macroecology and species' traits mediate competitive interactions in the order Lagomorpha. Mammal Review, 45(2), 88-102.

https://doi.org/10.1111/mam.12035

Published in:

Mammal Review

Document Version:

Peer reviewed version

Queen's University Belfast - Research Portal:

Link to publication record in Queen's University Belfast Research Portal

Publisher rights

(C) 2015 The Mammal Society and John Wiley \& Sons Ltd

This is the accepted version of the following article: Leach, K, Montgomery, WI \& Reid, N 2015, 'Biogeography, macroecology and species' traits mediate competitive interactions in the order Lagomorpha' Mammal Review, vol 45, no. 2, pp. 88-102, which has been published in final form at http://onlinelibrary.wiley.com/doi/10.1111/mam.12035/abstract.

\section{General rights}

Copyright for the publications made accessible via the Queen's University Belfast Research Portal is retained by the author(s) and / or other copyright owners and it is a condition of accessing these publications that users recognise and abide by the legal requirements associated with these rights.

\section{Take down policy}

The Research Portal is Queen's institutional repository that provides access to Queen's research output. Every effort has been made to ensure that content in the Research Portal does not infringe any person's rights, or applicable UK laws. If you discover content in the Research Portal that you believe breaches copyright or violates any law, please contact openaccess@qub.ac.uk. 
2 Biogeography, macroecology and species' traits mediate competitive interactions in the 3 order Lagomorpha

4 Katie LEACH* Quercus, School of Biological Sciences, Queen's University Belfast, Belfast, $5 \quad$ BT9 7BL, Northern Ireland.E-mail: kleach01@qub.ac.uk

6 W. Ian MONTGOMERY School of Biological Sciences, Queen's University Belfast, Belfast, BT9 7BL, Northern Ireland. E-mail: i.montgomery@qub.ac.uk

Belfast, BT9 5BN, Northern Ireland.E-mail: neil.reid@qub.ac.uk

$11 *$ Correspondence author

\section{ABSTRACT}

1. In addition to abiotic determinants, biotic factors, including competitive, interspecific

3. Thirty-three lagomorph species have competitive interactions reported in the literature; the majority involve hares (Lepus sp.) or the eastern cottontail rabbit (Sylvilagus floridanus). 
4. Closely related, large-bodied, similarly sized species occurring in regions of humanmodified, typically agricultural landscapes, or at high elevations are significantly more likely to have reported competitive interactions than other lagomorph species.

5. We identify species' traits associated with competitive interactions, and highlight some potential impacts that future environmental change may have on interspecific interactions. Our approach using bibliometric and biological data is widely applicable, and with relatively straightforward methodologies, can provide insights into interactions between species.

6. Our results have implications for predicting species' responses to global change, and we advise that capturing, parameterizing and incorporating interspecific interactions into analyses (for example, species distribution modelling) may be more important than suggested by the literature.

Submitted: 8 September 2014

Returned for revision: 21 October 2014

Revision accepted: 12 January 2015

Editor: $\mathrm{KH}$

Key words: $\quad$ Biotic interactions, climate change, competition, leporids, pikas.

Running head: Competitive interactions in the order Lagomorpha 


\section{INTRODUCTION}

Biotic interactions underpin a wide range of ecosystem processes and can occur between individuals of the same species (intraspecific interactions), or among individuals belonging to different species (interspecific interactions; Connell 1983, Chase et al. 2002). Interactions can take place at the local scale, for example, predation, parasitism, competition, and disturbance, or at the regional scale, for example, dispersal, speciation, extinction, and expansions or contractions of species' ranges (Cornell \& Lawton 1992, Amarasekare 2003). Competitive interactions are variously defined, but most definitions incorporate limited resources, for example: "the negative effects that one organism has upon another by consuming or controlling access to a resource that is limited in availability" (Keddy 2001). Strong competitive interspecific interactions at the same trophic level are likely to be due to occupied or partially occupied niche space which influences species' coexistence (Cornell \& Lawton 1992). Competition can be symmetrical, whereby there are equivalent negative effects, or asymmetrical, whereby there is a clear winner or loser (Connell 1983, Schoener 1983). Three mechanisms are known: (i) interference competition is when an individual directly affects another, for example, by using aggression (Birch 1957); (ii) exploitation competition is when individuals interact indirectly, usually competing for a common, limited resource (Keddy 2001); and (iii) apparent competition is when two individuals that do not compete directly for resources affect each other indirectly, by being prey for the same predator (Chaneton \& Bonsall 2000, Hatcher et al. 2006, DeCesare et al. 2010).

Competitive interactions tend to produce biogeographical patterns in species' distributions. Competing species may meet at a sharp boundary with little or no overlap, whereas noncompeting species' ranges may show complete overlap (Flux 2008). Parapatry is when two species have separate but contiguous ranges, with no physical barrier between them, and only co-occur, if at all, in a narrow contact zone (Bull 1991, Gutiérrez et al. 2014). Ranges of 
72 allopatric species are separated by a geographic barrier and, therefore, there can be no interspecific interaction. Sympatric species share the same geographical space, but may compete for access to similar habitats or resources. Alternatively, species occupying overlapping niches may not compete, so that their coexistence is possible due to the partitioning of resources. Exploitation competition may be evident if, for example, habitat use between species is comparable; abrupt habitat shifts at their point of contact in sympatry are likely to mirror the response to competition (Vidus-Rosin et al. 2011).

Traits of competitively interacting species have been studied in great detail (e.g. Schoener 1982, Luiselli 2006). Phylogenetic relatedness and its association with competition are often studied. Darwin (1859) suggested that closely related species are more likely to exhibit competition because they occupy similar ecological niches. Close relatedness of interacting species has since been shown experimentally (Violle et al. 2011), but does not hold for some taxa, for example, green algae (Venail et al. 2014). Species with larger body masses are more competitive because they are able to utilise a larger share of resources (Brown \& Maurer 1986) and similarly sized species are typically more likely to interact (Leyequien et al. 2007). Environmental traits can also influence competitive interactions, for example, competition is more likely in urban environments with higher human population densities (Shochat et al. 2006), and past climatic changes have probably caused large impacts on species' distributions and, therefore, on interspecific interactions (Koblmüller et al. 2012). Interactions between species are more common at high elevations (Jankowski et al. 2010), perhaps due to limited resources there, and are more vulnerable to change due to the predicted effects of climate change at such elevations (Chen et al. 2011), potentially changing species' ranges both directly and indirectly. Thus, environmental change, caused by human disturbance, changes in climate, or changes in land use, may have direct or indirect effects on the strength of biotic interactions, thus informing our interpretation of their likely influence on species' distributions. 
Interactions between species are extremely difficult to identify and quantify in the wild. Consequently, the impacts of global change on biotic interactions have rarely been studied (McCann 2007), but they are likely to be significant, due to related changes in phenology, behaviour, physiology, abundance and the co-occurrence of multiple species throughout biomes (e.g. Tylianakis et al. 2008). In the majority of cases, interactions are inferred from parapatry or species replacement, but this inference is not conclusive, and interactions could be a result of hybridization or adaptation to different habitats with no geographic overlap (Huey 1979). Competitive interspecific interactions may be altered by changes in dominant plants or animals under future environmental change; for example, increases in mean global temperatures could affect seed dehiscence times and change competition between mammalian seed predators and invertebrate seed dispersers (Ness \& Bressmer 2005). In a hypothetical situation in which species A, B and C are positioned along a resource gradient, with species A occupying the upper end (a region of high resource availability), species $\mathrm{C}$ occupying the lower end (a region of low resource availability), and species B occupying a niche between the two, any response to future environmental change involving an increase in the availability of resources may lead to selection favouring the more extreme species (A and C) and, hence, may lead to the expansion of their distributions (impacting species B). For example, species B could broaden its niche space, or new species could invade and occupy niche vacancies left by shifts in species A and/or C. However, if environmental change were to reduce the availability of resource types, the ranges of all three species may contract, which could increase the intensity of competition, and possibly lead to local extirpations at their contact zones, or total extinction(s) (Post 2013).

Lagomorphs are an important group of mammals economically and scientifically, as they are a major human food resource, model laboratory animals, valued game, significant agricultural pests, and key elements in food chains that provide scientific insights into entire trophic systems (Chapman \& Flux 2008). Competition among species in the order Lagomorpha can involve 
interference or exploitation for food or shelter (Vidus-Rosin et al. 2008). Interspecific competition is common between lagomorph species and is often precipitated by the introduction of non-native species (e.g. the European rabbit Oryctolagus cuniculus, the European hare Lepus europaeus, and the eastern cottontail Sylvilagus floridanus), leading to suppression or expulsion of native lagomorphs from certain habitats due to dominant behaviour and adaptive capabilities of the antagonist (Hackländer et al. 2008). Intraspecific competition in lagomorphs (Somers et al. 2012) and competition with other herbivores (Hulbert \& Andersen 2001, Bakker et al. 2009), on the other hand, has been rarely reported in the literature.

Lagomorphs are likely to be affected by environmental change because they occupy a wide range of environmental conditions in all continents except Antarctica, and because they are found at extreme elevations, from sea level to $>5,000 \mathrm{~m}$, and at very high latitudes, from the Equator to $80^{\circ} \mathrm{N}$ (Chapman \& Flux, 2008). A quarter of lagomorph species are listed in the International Union for Conservation of Nature's (IUCN) Red List of Threatened Species (www.iucnredlist.org); a notable number of species have highly restricted ranges, including 14 listed under the IUCN's Criterion B, with an extent of occurrence estimated to be less than $20,000 \mathrm{~km}^{2}$. Environmental change is predicted to have significant effects on lagomorphs, especially changes in climatic conditions (Ge et al. 2013, Mills et al. 2013), land use (Fa \& Bell 1990) and human disturbance (Schmidt et al. 2012), and is likely to have significant effects on lagomorph-lagomorph interactions. Research on parapatric hare species in Europe (Acevedo et al. 2012) showed that, under future climate scenarios, the Iberian hare Lepus granatensis is likely to be the beneficiary in competition with the European hare in their zone of contact in Northern Iberia, and interactions between the mountain hare Lepus timidus and the European hare are expected to contribute to the decline of the former in areas of co-occurrence in Northern Europe (Acevedo et al. 2012), for example, in Sweden (Thulin 2003) and Ireland (Reid 2011). 
We collate, review and assess all published data on lagomorph-lagomorph interactions, from both experimental evidence and inference from parapatry or species replacement, and examine the potential relationships between the environment and species' traits within different types of interaction. We aim to investigate how future environmental change may affect such interactions and potentially alter species' distributions. We predict greater competition between lagomorph species at higher elevations, due to restrictions in suitable habitat and in the range of potentially interacting species found in mountainous terrain, and in human-converted habitats, which are frequently inhabited by lagomorphs due to the availability of food (e.g. grasses or crops) and shelter (e.g. field margins and hedgerows providing cover) there. We expect the restricted range of food available in and the uniformity of anthropogenic landscapes to intensify competitive interactions. We also hypothesize that competitive interactions are more likely to occur between closely related species (i.e. those with shorter-than-average pairwise phylogenetic distances) with a small difference in body mass (i.e. those relatively similar in size). We use a combination of bibliometric analyses and biological data to assess traits associated with competitive interactions in an entire mammalian order, the Lagomorpha.

\section{METHODS}

\section{Capturing competitive interactions}

In the taxonomy we adopt, the Lagomorpha comprises 87 species in two families: the Ochotonidae consists of one monotypic group in the genus Ochotona containing 25 species of small, social pikas found at high latitudes, and usually high elevations; the Leporidae has 32 species of large, solitary, cursorial hares and jackrabbits in the genus Lepus and 30 species of medium-sized, semi-social, fossorial rabbits in 10 genera (Chapman \& Flux 2008; Ochotona nigritia and Ochotona gaoligongensis were classed as morphs of Ochotona forresti, Ochotona muliensis as a morph of Ochotona gloveri, Ochotona himalayana as a morph of Ochotona 
roylei and Ochotona huangensis as a morph of Ochotona thibetana following the taxonomic expertise of Dr Andrey Lissovsky, Zoological Museum of Moscow State University).

Data on interspecific interactions involving only lagomorphs were captured using the Web of Knowledge, searched using the terms "lagomorph AND interaction" or "lagomorph AND competition". Additional search terms included pairwise combinations of all species whose IUCN range polygons overlapped (using both scientific and common names) to identify the possibility of interactions not returned in the initial search. All 3,741 possible pairs of the 87 species in our taxonomy were classified as: (i) allopatric, i.e. exhibiting no range overlap, and lacking any published evidence of interspecific interactions; (ii) sympatric (i.e. with partially coincident geographical ranges, defined as overlap in their IUCN range polygons), but with no known interaction; or (iii) sympatric with interaction reported in the literature. Competitive interactions were classed as either exploitation or interference.

Information on interactions may be biased by body size or taxonomic group due to variable research effort (Brooke et al. 2014), and some pairwise interactions are likely to be undocumented in the literature to date; thus, the current study may have been vulnerable to type II errors or false negatives in identifying species' interactions. Moreover, there may have been a bias towards species showing interactions, due to researchers' preference for reporting significant effects: so-called 'publication bias' (Connell 1983). To take this potential bias into consideration, instead of assuming no competition between species for which there was no evidence of interaction, we defined category ii) as 'sympatric with no known interaction'.

\section{Spatial analysis}

The geographical range (based on the IUCN polygon) for each of the 33 species that had at least one documented interaction with another species was rasterised in ArcGIS 10.2 (ESRI, California, USA) at 30 arc-second resolution $\left(\sim 1 \mathrm{~km}^{2}\right.$ grid cells), with a value of 1 for presence 
and 0 for absence. The invasive range of the eastern cottontail in Italy was not included because IUCN polygons were only available for its native distribution. Rasterised data were summed to show the global distribution of possible interactions between species known to interact with at least one other species. Mean elevation $(\mathrm{m})$ and latitude $\left(^{\circ}\right)$ occupied by each pair of species known to interact were calculated at 30 arc-second resolution $\left(\sim 1 \mathrm{~km}^{2}\right.$ grid cells $)$.

\section{Species' traits and environmental data}

Phylogenetic distance, the amount of time since the most recent common ancestor of both species existed (Vellend et al. 2011), as a proxy for phenotypic differences between two species (Cavender-Bares et al. 2009), was quantified for each pair (including allopatric, sympatric with no known interaction and sympatric with interaction), to investigate whether closely related species were more likely to interact competitively. A lagomorph phylogeny was extracted from the mammalian supertree provided by Fritz et al. (2009). Likely clade membership for five species not included in this phylogeny was determined from Ge et al. (2013), and missing tips were grafted on using an expanded tree approach (Day et al. 2008). Pairwise phylogenetic distances were calculated using the 'ape' package (Paradis et al. 2014) for R version 3.1.1.

Species' traits, including body mass (grams) and human population density (people $/ \mathrm{km}^{2}$ ) within each species' range, were taken from the PanTHERIA database (Jones et al. 2009). Ecoregional climatic stability data was provided by Takuya Iwamura (Iwamura et al. 2013), and was defined as "the proportion of an ecoregion which is predicted to be climatically stable under [future] climate change." The climatic stability index is calculated by estimating the overlap between present and future climatic envelopes for each ecoregion, using results from seven global circulation models. It ranges from 0 (no overlap between current and future climates) to 1 (complete overlap and high robustness to climate change; Watson et al. 2013). 
For each species, the percentage of occurrence records in human-converted habitats was included as a coarse measure of the threat to each species from human activities, following Hoekstra et al. (2005). Converted habitats included cultivated or managed land and artificial surfaces; areas were derived from a modified version of the Global Land Cover 2000 dataset (Anonymous, 2003). The occurrence data used in this calculation comprised 41,874 records that were either downloaded from the Global Biodiversity Information Facility data portal (data.gbif.org), collated from experts or members of the IUCN Species Survival Commission Lagomorph Specialist Group, and/or extracted from the literature for data-deficient species. Taxonomic accuracy was ensured by checking all records against the latest IUCN taxonomy; if names did not match after cross-referencing with taxonomic synonyms and previous names, records were rejected. Spatial data accuracy was ensured by removing any records that were obviously erroneous because they fell outside the extent of the IUCN geographic range polygon. In addition, occurrences recorded with a spatial resolution of $>2 \mathrm{~km}$ were removed, and duplicate records were eliminated. Species' traits considered (examined) but not included in the analysis are listed in Appendix S1.

\section{Statistical analyses}

233 A linear regression was performed in $\mathrm{R}$ version 3.1 .1 to test the relationship between the dependent variable, elevation $(\mathrm{m})$, and the number of possible pairwise interactions (rasterised data from the Spatial analysis section). A Generalized Linear Model was used to evaluate differences between pairs of species allocated to the three interaction types: (i) allopatric, (ii) sympatric with no known interaction and (iii) sympatric with interaction, using a number of species' traits as explanatory variables (phylogenetic distance, mean body mass, similarity in body mass, mean ecoregional climatic stability, mean human population density and mean percentage of occurrence records in human-converted habitats). 


\section{RESULTS}

\section{Spatial patterns of interspecific interactions}

243 Of the 3,741 possible pairs between the 87 species of lagomorph, 3,489 were classed as 244 allopatric, 219 were classed as sympatric with no known interaction, and 33 were classed as 245 sympatric with documented interaction; of the 33 species involved in the 33 documented 246 interactions, nine were pikas, eight were rabbits and 16 were hares (Table 1). The distribution of 247 documented interspecific interactions was not uniform but clustered in eastern Asia (exclusively pikas) and North America (rabbits, hares and jackrabbits; Fig. 1a). Six of the interactions involved interference competition, and five of these (83\%) involved the eastern cottontail. The global distribution of possible pairwise interactions between lagomorph species (Fig. 1b) showed that in large areas ( $\sim 69 \%$ of the total global range of the order Lagomorpha), no documented pairwise interactions exist (Fig. 1c); lagomorph species were 2.2 times more likely to occur in allopatry than in sympatry, and 3.1 times more likely to be involved in just one pairwise interaction than in multiple interactions. The mean number of potential pairwise interactions globally was $1.51 \pm 0.78(\mathrm{SD})$. Only small areas of the globe contained the highest concentrations of possible interactions; for example, there were six possible pairwise species interactions in a $6,000 \mathrm{~km}^{2}$ area in southern Russia on the border of Mongolia (Fig. 1c), with interactions clustered around $30-50^{\circ} \mathrm{N}$ of the Equator (Fig. 1d). There was a significant positive association between the number of possible pairwise interactions and elevation $\left(F_{3,49917}=731.8\right.$, $p<0.001$; Fig. 2).

\section{Linking interactions to species' traits and environmental change}

262 Sympatric pairs of species with documented pairwise interactions had significantly shorter phylogenetic distances between them than pairs of species that occurred in sympatry but had no known interaction $\left(\mathrm{F}_{2}, 3738=19.8, p<0.001\right.$; Fig. 3a, see Appendix S2). Thus, within the order 
Lagomorpha, sympatric species with documented competitive interactions were 2.3 times more closely related than sympatric species with no known interaction.

The mean body mass of pairs of interacting sympatric species was significantly greater $\left(\mathrm{F}_{2}\right.$, $3738=22.3, p<0.001$ ) than that of pairs of sympatric species that had no known interaction (Fig. 3b, Appendix S2). The mean body mass of pairs of allopatric species was lower than both. However, whilst interacting species tended to be heaviest, analysis of the difference in body mass between species in each pair showed that pairs of interacting species were significantly closer in mass than pairs of allopatric species and sympatric species with no known interaction (Fig.3c, Appendix S2).

There was no difference in mean ecoregional climatic stability between the pairwise interaction types $\left(\mathrm{F}_{2}, 3738=0.03, p=0.969\right.$; Fig. $3 \mathrm{~d}$, Appendix S2). The mean ecoregional climatic stability index value for the order Lagomorpha was $0.46 \pm 0.14$, which is similar to, but slightly higher than, the global average of $0.42 \pm 0.03$.

Pairs of sympatric species were more likely to occur in regions of high human population density, but due to the variability in human population density in regions supporting lagomorphs, the difference between sympatric groups was not significant (Fig. 3e, Appendix S2). However, there was a significant difference in mean human population density between the ranges of pairs of allopatric species and those of sympatric species with a known interaction $\left(\mathrm{F}_{2}, 3738=5.02\right.$, $p<0.001$; Fig. 3e). Interacting pairs of sympatric species occurred significantly more frequently in human-converted habitats than pairs of sympatric species with no known interaction $\left(\mathrm{F}_{2,3738=}\right.$ $6.3, p=0.002$ ), and pairs of sympatric species with no known interaction were significantly more frequently found in human-converted habitats than pairs of allopatric species $\left(F_{2}, 3738=6.3\right.$, $p=0.002$; Fig. 3f, Appendix S2). 


\section{REVIEW AND DISCUSSION}

290 Closely related, large-bodied, similarly-sized species occurring in regions of human-modified, 291 typically agricultural landscapes, or at high elevations, were significantly more likely to exhibit competitive interactions than other species within the order Lagomorpha. The greatest changes in species' ranges are likely to occur either at high elevation, where the effects of climate warming are pronounced (Chen et al. 2011), or in human-modified habitats, which are already subject to significant threats and pressures (McCarthy et al. 2010). This suggests that interacting species, which are found more commonly in human-modified habitats and at high elevation, are likely to be highly susceptible to future environmental changes. Moreover, the average ecoregional climatic stability index for regions inhabited by lagomorphs, although slightly higher than the global average, indicates only medium robustness of those regions to future changes in climatic conditions. Larger mammalian species are predicted to be especially vulnerable to future climatic changes (McCain \& King 2014). Many of the responses to climate change in large mammals, e.g. the Eurasian elk Alces alces, are in fact positive, but large species are nevertheless vulnerable to change. In addition, we expect closely related species to show similar responses to environmental change, although idiosyncratic responses are predicted to be more likely (Tafani et al. 2013).

\section{Experimental evidence of competition}

Thirty-three pairwise interspecific interactions were identified within the order Lagomorpha, but the evidence for the majority of these competitive interactions was from opportunistic, isolated field observations inferred from parapatry or species replacement. Only one study to date (Probert \& Litvaitis 1996), provides experimental evidence of competition in lagomorphs:

311 interference competition between the eastern cottontail and the New England cottontail 
Johnston 1972), has led to the expansion of the former and a decline in abundance of the latter. It is possible that the eastern cottontail is a better competitor than the New England cottontail due to inbreeding in transplanted locations which, by increasing the genetic variability of offspring, has functionally enabled occupation of a broad range of habitats (Litvaitis et al. 2008) and also because it is approximately 20\% larger. The experimental trial by Probert and Litvaitis (1996), however, showed that eastern cottontails were dominant in only $42 \%$ of trials, suggesting that factors other than physical dominance may explain their colonisation of habitats. Eastern cottontails are likely to be dominant because they use open habitats (Smith \& Litvaitis 2000), can detect predators at greater distances (Smith \& Litvaitis 1999), and have better dispersal capabilities (Probert \& Litvaitis 1996) than New England cottontails.

Interference competition, as recorded by Probert and Litvaitis (1996), is attributable only to a commonly displacing other species from shared habitats (Litvaitis et al. 2008). Our results suggest that the eastern cottontail occupies a region of average climate stability $(\sim 0.36)$, with higher than average mean human population density (267 individuals $/ \mathrm{km}^{2}$ ) and higher than average occurrence within human-converted habitats (44\%). Occupation of areas vulnerable to anthropogenic change may lead to heightened aggression in competitive interactions between the eastern cottontail and other lagomorphs, e.g. pygmy rabbits Brachylagus idahoensis, brush rabbits Sylvilagus bachmani, forest rabbits Sylvilagus brasiliensis, mountain cottontails Sylvilagus nuttallii and New England cottontails, but further comparative analysis of species' traits may be required to identify the mechanisms behind its uniquely aggressive, competitive interactions. 
339 Competitive interactions are not easily identified in the wild, and even when they are, most 340 competition is inferred from parapatry or species replacement. Due to limited data, we 341 considered two species to be competitively interacting even if there was only one record 342 providing supporting evidence, i.e. either an experimental study or inference from parapatry or 343 species replacement. However, the weaknesses of inferring competition should be noted. 344 Parapatric distributions and species replacement are consistent with intraspecific competition, 345 but evidence is far from conclusive. Huey (1979) states that parapatry is often used as evidence 346 for competition, and parapatric distributions can in fact result from intense interspecific competition, but they may also arise from hybridization or from adaptation of species to different habitats that do not overlap geographically. Nevertheless, with scarcely any experimental demonstration of competitive interactions in lagomorphs, information on parapatric distributions and species replacement is all we have at present to review competition within the order.

Hares of the genus Lepus are typically allopatric, but in a few notable cases they exhibit parapatry. For example, in Europe there are five Lepus species: the Apennine hare Lepus corsicanus and broom hare Lepus castroviejoi have restricted allopatric ranges, whereas the European hare, mountain hare and Iberian hare have much wider ranges. Competition between the latter three species is asymmetrical and in most cases the ranges are parapatric (Acevedo et al. 2012). In the contact zone between Iberian and European hares, there is a decrease in 358 abundance of the latter (Gortázar et al. 2007), the European hare competes with the Apennine hare (Angelici et al. 2008) and there tends to be contraction of mountain hare ranges, in extent and elevation, in contact zones with the European hare (Thulin 2003, Reid 2011). In most of the European hare's native range, the mountain hare seems to be restricted to high elevations and 362 forests, as it is driven away from lowland grassland plains (Thulin 2003, Flux 2008), but in 
Ireland, Finland, Russia and Sweden, the European hare, which was introduced in the late $19^{\text {th }}$ and early $20^{\text {th }}$ centuries, is found in sympatry with the mountain hare (Flux 2008). In Ireland, introduced European hares and endemic Irish hares Lepus timidus hibernicus occupy similar habitats in sympatry (Reid \& Montgomery 2007). They would probably show strong interspecific competition if resources were limiting (Reid 2011), but this is highly unlikely as the majority of available habitat is grassland and thus optimal for both species. Nevertheless, the European hare has actively displaced the Irish hare within its core invasive range, creating a zone of European hare allopatry (Caravaggi et al. 2014).

'Extinction by hybridization' was originally described by Rhymer and Simberloff (1996) as a possible effect of hybridization between native and introduced species. If there were a large number of hybrid events between female mountain hares and male European hares, then speciesspecific litters would be lost in mountain hare populations, causing a loss of range and decline in population density (Thulin 2003). In Sweden, where the two species hybridize in sympatry, the mitochondrial DNA (mtDNA) from mountain hares is transferred to European hares, but this pattern gradually disappears in areas of allopatry (Thulin \& Tegelström 2002). Only one researcher to date (Lind 1963) has examined competition between mountain hares and European hares; competitive exclusion of mountain hares and significant differences in food preference and habitat utilisation were found. However, European hares and mountain hares have often been observed feeding side by side (Hewson 1990).

Species displacement through hybridization is not a new phenomenon restricted to secondary contact after anthropogenic introductions of alien species into the ranges of old adversaries; 'ancient hybridisation' is prevalent within the order Lagomorpha such that many species actually share mitochondrial or nuclear haplotypes revealing the 'ghosts of a hybrid past' (Paulo Célio Alves, pers. comms. citing Wilson \& Bernatchez 1998). Mountain hare mtDNA lineages are found throughout Europe within European hares, Iberian hares and broom hares (Melo-Ferreira 
et al. 2009). Such ancient hybridization is likely to have occurred during the last glacial maximum when the mountain hare's range would have extended further south than today. Moreover, European hares, Iberian hares and Apennine hares are also known to have hybridized in ancient times (Pietri et al. 2011). The phenomenon is pervasive, being present also in Asia (Liu et al. 2011) and North America. For example, snowshoe hare Lepus americanus mtDNA lineages in the Greater Pacific Northwest exhibit hybrid introgression from black-tailed jackrabbits Lepus californicus,, despite the minimal overlap of their current geographic ranges (Cheng et al. 2014, Melo-Ferreira et al. 2014). For the purposes of this study, ancient hybridization and introgression will not be considered any further as they do not represent ongoing competitive behavioural interactions.

The majority of competitive interactions occurred between hares in the genus Lepus and observed (Best \& Henry 1993); antelope jackrabbits Lepus alleni have been replaced by blacktailed jackrabbits in some habitats (Chapman \& Flux 1990); snowshoe hares in Wisconsin, USA were replaced by white-tailed jackrabbits (Leopold 1947); and white-tailed jackrabbits were replaced by black-tailed jackrabbits (Flinders \& Chapman 2003). The Abyssinian hare Lepus savannah hare Lepus microtis, scrub hare Lepus saxatilis) and Ethiopian hare Lepus fagani in others (Chapman \& Flux 1990). The African savannah hare is replaced by the scrub hare (Flux 2008), and the Manchurian hare Lepus mandshuricus and European hare are replaced by the

Tolai hare Lepus tolai in Russian Asia (Fadeev 1966, Chapman \& Flux 1990, Smith \& Xie 2008,

Sokolov et al. 2009). Competition amongst hares is inferred in many cases because a species is observed occupying the preferred habitat of another species in its absence, but it can also be 
inferred due to the rare and transient nature of sympatric hare co-occurrence (Flux 1981). Hare species often exhibit parapatric distributions and only tend to occur, if at all, temporarily in the same habitat (Acevedo et al. 2012). Despite a lack of any experimental demonstration of competitive exclusion in lagomorphs, this may nevertheless be a very powerful determinant of geographical and local ranges (Flux 1981, Thulin 2003).

Large areas, globally, were occupied by lagomorphs for which there was no evidence of interaction, suggesting that allopatry or parapatry is the usual situation, and that interspecific contact is globally restricted and occurs only in relatively narrow contact zones. However, our spatial analysis would not reveal that species could occupy the same range but be functionally separated by habitat, e.g. mountain hares and European hares are separated by elevation within parts of their contact zone (Thulin 2003). Thus, not all sympatric species will have the opportunity to interact directly and, if they do, interactions may occur in a smaller range than that suggested by our spatial analysis. In addition, population dynamics rather than competition may cause a decline in the abundance of one species, leading to movement of the more abundant species and hence replacement of one species by another in a particular habitat.

Hares and rabbits frequently co-occur, but rarely interact. The European hare and the European rabbit form one of the most commonly studied and observed systems with respect to competition. Before anthropogenic introductions, the European hare was restricted to central Europe and the Asian steppes, and the European rabbit to the Iberian Peninsula (Flux 1994), but overlap in the ranges of these two species is now widespread, and coexistence occurs in many introduced populations (Flux 2008). Allopatry is seen at regional scales due to habitat preferences (e.g. Petrovan 2011), and there is widespread belief that the species avoid each other (e.g. Cox 1976). However, in most areas of their range they graze side by side, showing significant dietary overlap (e.g. Katona et al. 2004). Various reports from the early $20^{\text {th }}$ century 
note physical attacks of rabbits on hares both in captivity and in the wild (Gayot 1868, Millais 1906), but more recent observations indicate that aggressive antagonism is rare (e.g. Flux 2008).

Rabbits from other genera, for example Bunolagus, Poelagus and Pronolagus, coexist with hares without physical aggression, and there appear to be no antagonistic interactions between rabbits and jackrabbits (Orr 1940, Flux 2008). However, competition with the black-tailed jackrabbit may affect the distribution of the desert cottontail (AMCELA (Mexican Association for Conservation and Study of Lagomorphs) et al. 2008) and competition may have occurred in at least some areas between the mountain cottontail and the snowshoe hare (Frey \& Malaney 2006), although more studies are needed to confirm this interaction. Leporids, for example the black-tailed jackrabbit, eastern cottontail and desert cottontail, may compete with pygmy rabbits for burrows (e.g. Pierce et al. 2011), cape hares may displace the riverine rabbit Bunolagus monticularis in marginal habitat (Duthie 1989) and competition between introduced eastern cottontails in Italy and European hares and rabbits is likely, due to marked differences in habitat selection for feeding and resting in sympatric and allopatric areas (Vidus-Rosin et al. 2011, 2012), but has yet to be observed (e.g. Bertolino et al. 2013). In addition, aggressive competitive interactions are documented between the eastern cottontail, brush rabbit and mountain cottontail in North Dakota, USA (Chapman \& Verts 1969, Genoways \& Jones 1972) and between the eastern cottontail and the forest rabbit in expanding savannah and scrub habitats of South America (Chapman \& Flux 1990).

Two species of pika in North America, the American pika Ochotona princeps and the collared pika Ochotona collaris, show no overlap in range, whereas the ranges of the twentythree Asian pikas exhibit large degrees of overlap, yet most have no reported interaction in the published literature. The plateau pika Ochotona curzoniae excludes the Daurian pika Ochotona dauurica and the Gansu pika Ochotona cansus from open alpine meadows (Chapman \& Flux 1990, Su 2001, Zhang et al. 2001), and Kozlov's pika Ochotona koslowi is excluded from the 
462 Guldsha valley, Pakistan, by the plateau pika Ochotona curzoniae and the Ladak pika Ochotona 463 Ladacensis (Büchner 1894). In sympatric areas, alpine pikas Ochotona alpina and northern pikas 464 Ochotona hyperborea compete for shelter, and northern pikas are smaller in sympatry than in 465 allopatry (Chapman \& Flux 1990). Interference competition has been reported between Pallas's 466 pikas Ochotona pallasi and steppe pikas Ochotona pusilla in peak population years (Sokolov et 467 al. 2009). Pallas's pika is more successful due to its aggressiveness and dispersal ability 468 (Smirnov 1974).

Two invasive interactions were identified in our literature review: between the European and the mountain hare in Sweden and Ireland (Thulin 2003, Reid, 2011), and between the European hare and the forest rabbit in Argentina (Novillo \& Ojeda 2008). Inclusion of these species into the analysis did not have substantial effects on the overall patterns observed; however, we did find that these invasive interactions occupied regions with higher than average human population density and human-converted habitats, and regions which were on average more climatically unstable. Other researchers have found increased occurrence of invasive species in areas of high human population density (e.g. McKinney 2001), and our finding indicates that the interactions between these lagomorph species pairs may be heavily influenced by future human disturbance as well as by climatic changes (e.g. Schmidt et al. 2012). Invasive interactions between the eastern cottontail and native Italian lagomorphs are also possible, however at present there is no available IUCN polygon for the invasive range and competition is yet to be observed (e.g. $481 \quad$ Bertolino et al. 2013).

\section{Conclusion}

Our results have implications for predicting lagomorph responses to global change, and suggest that capturing, parameterizing and incorporating interspecific interactions into analyses may be more important than suggested by the literature, for example, when applying species distribution 

modelling (Acevedo et al. 2012). Future behavioural observation studies should focus on areas 487 of sympatry, particularly those areas in which Lepus species occur in a narrow contact zone or in 488 species-rich regions (most notably, the hotspots in southern Russia on the border of Mongolia 489 and north western USA), to increase our knowledge of competitive interactions in the order 490 Lagomorpha. The combination of bibliometric analyses and biological data used in this study 491 allowed us to identify traits associated with competitively interacting species and highlight the 492 potential impacts of future environmental change. This approach is widely applicable, and with 493 relatively straightforward methodologies, can provide significant insights into interactions 494 between species. 
497 This project was funded by Quercus, Northern Ireland's Centre for Biodiversity and 498 Conservation Science supported by the School of Biological Sciences, Queen's University 499 Belfast. We thank Michael Barbour, Kai Collins, Christy Bragg, Deyan Ge, David Hik, Dana 500 Lee, Andrew Smith, Franz Suchentrunk, Zelalem Tolesa and Weihe Yang for contributing 501 species' occurrence data. Particular thanks go to Andrey Lissovsky for taxonomic expertise and 502 for contributing data. We also thank two anonymous reviewers and Nancy Jennings for 503 comments that greatly improved the manuscript. 


\section{REFERENCES}

506 Acevedo P, Jimenez-Valverde A, Melo-Ferreira J, Real R, Alves PC (2012) Parapatric species and the implications for climate change studies: a case study on hares in Europe. Global Change Biology 18: 1509-1519.

Amarasekare P (2003) Competitive coexistence in spatially structured environments: a synthesis. Ecology Letters 6: 1109-1122.

AMCELA (Mexican Association for Conservation and Study of Lagomorphs), Romero Malpica, FJ, Rangel Cordero, H (2008) Sylvilagus audubonii. IUCN Red List of Threatened Species.

Angelici FM, Randi E, Riga F, Trocchi V (2008) Lepus corsicanus. IUCN Red List of

Best TL, Henry TH (1993) Lepus callotis. American Society of Mammologists, Mammalian

Bertolino S, Cordero di Montezemolo N, Perrone A (2013) Habitat use of coexisting introduced eastern cottontail and native European hare. Zeitschrist für Säugetierkunde 78: 235-240.

Birch LC (1957) The meanings of competition. American Naturalist 91: 5-18. 
Brooke ZM, Bielby J, Nambiar K, Carbone C (2014) Correlates of research effort in carnivores: body size, range size and diet matter. PLOS ONE, 9: e93195.

Brown JH, Maurer BA (1986) Body size, ecological dominance and Cope's rule. Nature 324: 248-250.

Büchner E (1894) Wissenschaftliche Resultate der von N. M. Przewalski nach central-Asien unternommenen Reisen auf Kosten einer von seiner Kaiserliche Hoheit dem Grossfursten Thronfolger Nikolai Alexandrowitsh gespendeten Summe herausgegeben von der Kaiserlichen Akademie der Wissenschaften St. Petersburg. Zoologischer, Theil. Band I. Saugethiere 5: 185-232.

Bull CM (1991) Ecology of parapatric distributions. Annual Review of Ecology and Systematics 22: $19-36$.

Caravaggi A, Montgomery WI, Reid N (2014) Range expansion and comparative habitat use of insular, congeneric lagomorphs: invasive European hares Lepus europaeus and endemic Irish hares Lepus timidus hibernicus. Biological Invasions, 17: 687-698.

Cavender-Bares J, Kozak KH, Fine PVA, Kembel SW (2009) The merging of community ecology and phylogenetic biology. Ecology Letters 12: 693-715.

Chaneton EJ, Bonsall MB (2000) Enemy-mediated apparent competition: empirical patterns and the evidence. Oikos 88: 380-394.

Chapman JA, Flux JEC (1990) Rabbits, Hares and Pikas: Status Survey and Conservation Action Plan. IUCN, Gland, Switzerland. 
Chapman JA, Flux JEC (2008) Introduction to the Lagomorpha. In: Alves PC, Ferrand N, Hackländer K (eds) Lagomorph Biology: Evolution, Ecology and Conservation, 1-9. Springer-Verlag Berlin Heidelberg, Germany.

Chapman JA, Verts BJ (1969) Interspecific aggressive behaviours in rabbits. Murrelet 50: 17-18.

Chase JM, Abrams PA, Grover JP, Diehl S, Chesson P, Holt RD, Richards SA, Nisbet RM, Case TJ (2002) The interaction between predation and competition: a review and synthesis. Ecology Letters 5: 302-315.

Chen IC, Hill JK, Ohlemüller R, Roy DB, Thomas CD (2011) Rapid range shifts of species associated with high levels of climate warming. Science 333: 1024-1026.

Cheng E, Hodges KE, Melo-Ferreira J, Alves PC, Mills LS (2014) Conservation implications of the evolutionary history and genetic diversity hotspots of the snowshoe hare. Molecular Ecology 23: 2929-2942.

Connell JH (1983) On the prevalence and relative importance of interspecific competition: evidence from field experiments. American Naturalist 122: 661-696.

Cornell HV, Lawton JH (1992) Species interactions, local and regional processes and limits to the richness of ecological communities: a theoretical perspective. Journal of Animal Ecology 61: 1-12.

Cox R (1976) A day in the life of a rabbiter. NZ Outdoor 41: 23-25.

Darwin C (1859) On the Origin of Species by Means of Natural Selection, or the Preservation of Favoured Races in the Struggle for Life. Murray, London, UK.

Day JJ, Cotton JA, Barraclough TG (2008) Tempo and mode of diversification of Lake Tanganyika Cichlid Fishes. PLOS ONE 3: e1730. 
DeCesare NJ, Hebblewhite N, Robinson HS, Musiani M (2010) Endangered, apparently: the role of apparent competition in endangered species conservation. Animal Conservation 13: 353362.

Duthie AG (1989) The ecology of the riverine rabbit (Bunolagus monticularis). MSc thesis, University of Pretoria, South Africa.

Fa JE, Bell DJ (1990) Chapter 12: The volcano rabbit Romerolagus diazi. In: Chapman JA, Flux JC (eds) Rabbits, Hares and Pikas: Status Survey and Conservation Action Plan, 143-146. IUCN, Gland, Switzerland.

Fadeev VA (1966) The diet and daily rhythms of the brown hare in western Kazahkstan. Nauka, Moscow-Leningrad, Russian Federation.

Flinders JT, Chapman JA (2003) Chapter 6: Black-tailed Jackrabbit. In: Feldhammer GA, Thompson BC, Chapman JA (eds) Wild Mammals of North America: Biology, Management and Conservation, 126-146. John Hopkins University Press, Baltimore, Maryland, USA.

Flux JEC (1981) Field observations of behaviour in the genus Lepus. In: Myers K, MacInnes CD (eds) Proceedings of the World Lagomorph Conference, University of Guelph, Guelph, Canada, 337-394.

Flux JEC (1994) World distribution. In: Thompson HV, King CM (eds) The European Rabbit. The History and Biology of a Successful Coloniser, 8-17. Oxford University Press, Oxford, UK.

Flux JEC (2008) A review of competition between rabbits (Oryctolagus cuniculus) and hares (Lepus europaeus). In: Alves PC, Ferrand N, Hackländer K (eds) Lagomorph Biology: Evolution, Ecology and Conservation, 241-249. Springer-Verlag Berlin Heidelberg, Germany. 
591 Frey JK, Malaney JL (2006) Snowshoe hare (Lepus americanus) and mountain cottontail 592 (Sylvilagus nuttallii) biogeography at their southern range limit. Journal of Mammalogy 87: $593 \quad 1175-1182$.

594 Fritz SA, Bininda-Emonds OR, Purvis A (2009) Geographical variation in predictors of 595 mammalian extinction risk: big is bad, but only in the tropics. Ecology Letters 12: 538-549. 596 Gayot E (1868) Lievres, alpins et leporids. Comptes rendus de l'Academie des sciences 12: 1$597 \quad 456$.

598 Ge D, Wen Z, Xia L, Zhang Z, Erbajeva M, Huang C, Yang Q (2013) Evolutionary history of $599 \quad$ lagomorphs in response to global environmental change. PLOS ONE 8: e59668.

600 Genoways HH, Jones Jr JK (1972) Mammals from south-western North Dakota. Occasional 601 Papers, Museum of Texas Tech University 6: 1-36.

602 Gortázar C, Millán J, Acevedo P, Escudero MA, Marco J, Fernández de Luco D (2007) A large603 scale survey of brown hare Lepus europaeus and Iberian hare L. granatensis populations at 604 the limit of their ranges. Wildlife Biology 13: 244-250.

605 Gutiérrez EE, Boria RA, Anderson RP (2014) Can biotic interactions cause allopatry? Niche 606 models, competition and distributions of South American mouse opossums. Ecography 37: $607 \quad 741-753$.

608 Hackländer K, Ferrand N, Alves PC (2008) Overview of lagomorph research: what we have 609 learned and what we still need to do. In: Alves PC, Ferrand N, Hackländer K (eds) 610 Lagomorph Biology: Evolution, Ecology and Conservation, 381-391. Springer-Verlag Berlin 611 Heidelberg.

612 Hatcher MJ, Dick JTA, Dunn AM (2006) How parasites affect interactions between competitors 613 and predators. Ecology Letters 9: 1253-1271. 
614 Hewson R (1990) Interactions between mountain hares (Lepus timidus) and other mammals. $615 \quad$ Journal of Zoology 221: 302-305.

616 Hoekstra JM, Boucher TM, Ricketts TH, Roberts C (2005) Confronting a biome crisis: global 617 disparities of habitat loss and protection. Ecology Letters 8: 23-29.

618 Huey RB (1979) Parapatry and niche complementarity of Peruvian Desert Geckos 619 (Phyllodactylus): the ambiguous role of competition. Oecologia 38: 249-259.

620 Hulbert IAR, Andersen R (2001) Food competition between a large ruminant and a small 621 hindgut fermentor: the case of the roe deer and mountain hare. Oecologia 128: 499-508.

622 Iwamura T, Guisan A, Wilson KA, Possingham HP (2013) How robust are global conservation 623 priorities to climate change? Global Environmental Change 23: 1277-1284.

624 Jankowski JE, Robinson SK, Levey DJ (2010) Squeezed at the top: interspecific aggression may 625 constrain elevational ranges in tropical birds. Ecology 91: 1877-1884.

626 Johnston JE (1972) Identification and distribution of cottontail rabbits in southern New England. 627 MS Thesis, University of Connecticut, Storrs.

628 Jones KE, Bielby J, Cardillo M, Fritz SA, O’Dell J, Orme CDL et al. (2009) PanTHERIA: a 629 species-level database of life history, ecology and geography of extant and recently extinct $630 \quad$ mammals. Ecology 90: 2648.

631 Katona K, Biro Z, Hahn I, Kertész M, Altbäcker V (2004) Competition between European hare 632 and European rabbit in a lowland area, Hungary: a long-term ecological study in the period 633 of rabbit extinction. Folia Zoology 53: 255-268.

634 Keddy PA (2001) Competition (2 ${ }^{\text {nd }}$ edition). Kluwer Academic Publishers, Dordrecht. 
635 Koblmüller S, Wayne RK, Leonard JA (2012) Impact of Quartenary climatic changes and 636 interspecific competition on the demographic history of a highly mobile generalist carnivore, 637 the coyote. Biology Letters 8: 644-647.

638 Leopold A (1947) The distribution of Wisconsin hares. Transactions of the Wisconsin Academy 639 of Sciences, Arts and Letters 37: 1-14.

640 Leyequien E, de Boer WF, Cleef A (2007) Influence of body size on coexistence of bird species. $641 \quad$ Ecological Research 22: 735-741.

642 Lind EA (1963) Observations on the mutual relationship between the snow hare (Lepus timidus) 643 and the field hare (L.europaeus). Suomen Riista 16: 128-135.

644 Litvaitis JA, Barbour MS, Brown AL, Kovach AI, Litvaitis MK, Oehler JD, Probert BL, Smith 645 DF, Tash JP, Villafuerte R (2008) Testing multiple hypotheses to identify causes of the 646 decline of a lagomorph species: the New England cottontail as a case study. In: Alves PC, 647 Ferrand N, Hackländer K (eds) Lagomorph Biology: Evolution, Ecology and Conservation, 648 167-185. Springer-Verlag Berlin Heidelberg, Germany.

649 Liu J, Yu L, Arnold ML, Wu C-H, Wu S-F, Lu X, Zhang Y-P (2011). Reticulate evolution: 650 frequent introgressive hybridization among Chinese hares (genus Lepus) revealed by 651 analyses of multiple mitochondrial and nuclear DNA loci. BMC Evolutionary Biology 11: $652 \quad 223-237$.

653 Luiselli L (2006) Resource partitioning and interspecific competition in snakes: the search for 654 general geographical and guild patterns. Oikos 114: 193-211.

655 McCain CM, King SRB (2014) Body size and activity times mediate mammalian responses to 656 climate change. Global Change Biology 20: 1760-1769. 
McCann K (2007) Protecting biostructure. Nature 446: 29.

McCarthy MP, Best MJ, Betts RA (2010) Climate change in cities due to global warming and urban effects. Geophysical Research Letters 37: L09705.

McKinney ML (2001) Effects of human population, area, and time on non-native plant and fish diversity in the United States. Biological Conservation 100: 243-252.

Melo-Ferreira J, Alves PC, Freitas H, Ferrand N, Boursot P (2009) The genomic legacy from the extinct Lepus timidus to the three hare species of Iberia: contrast between mtDNA, sex chromosomes and autosomes. Molecular Ecology 18: 2643-2658.

Melo-Ferreira J, Seixas FA, Cheng E, Mills LS, Alves PC (2014) The hidden history of the snowshoe hare, Lepus americanus: extensive mitochondrial DNA introgression inferred from multilocus genetic variation. Molecular Ecology 23: 4617-4630.

Millais JG (1906) The mammals of Great Britain and Ireland. Longmans, Green \& Co, London.

Mills LS, Zimova M, Oyler J, Running S, Abatzoglou JT, Lukacs PM (2013) Camouflage mismatch in seasonal coat colour due to decreased snow duration. PNAS 110: 7360-7365.

Ness JH, Bressmer K (2005) Abiotic influences on the behaviour of rodents, ants, and plants affect an ant-seed mutualism. Ecoscience 12: 76-81.

Novillo A, Ojeda RA (2008) The exotic mammals of Argentina. Biological Invasions 10: 13331344.

Orr RT (1940) The rabbits of California. Occasional Papers of the California Academy of Sciences 19: 1-227.

Paradis E, Blomberg S, Bolker B, Claude J, Cuong HS, Desper R et al. (2014) ape: Analyses of phylogenetics and evolution. R Package version 3.0-11. 
679 Petrovan SO (2011) The landscape ecology of brown hares and European rabbits in pastures in 680 the north east of England. PhD thesis, University of Hull, Hull, UK.

681 Pierce JE, Larsen RT, Flinders JT, Whiting JC (2011) Fragmentation of sagebrush communities: 682 does an increase in habitat edge impact pygmy rabbits? Animal Conservation 14: 314-321.

683 Pietri C, Alves PC, Melo-Ferreira J (2011) Hares in Corsica: high prevalence of Lepus 684 corsicanus and hybridization with introduced L.europaeus and L.granatensis. European 685 Journal of Wildlife Research 57: 313-321.

686 Post E (2013) Ecology of Climate Change: the importance of biotic interactions. Princeton 687 University Press, Princeton, New Jersey, USA.

688 Probert BL, Litvaitis JA (1996) Behavioural interactions between invading and endemic 689 lagomorphs: implications for conserving a declining species. Biological Conservation 76: $690 \quad 289-296$.

691 Reid N, Montgomery WI (2007) Is naturalisation of the brown hare in Ireland a threat to the 692 693 endemic Irish hare? Biology and Environment: Proceedings of the Royal Irish Academy 107b: $129-138$.

694 695 696 697 698

Reid N (2011) European hare (Lepus europaeus) invasion ecology: implication for the conservation of the endemic Irish hare (Lepus timidus hibernicus). Biological Invasions 13: 559-569.

Rhymer JM, Simberloff D (1996) Extinction by hybridization and introgression. Annual Review in Ecology and Systematics 27: 83-109. 
699 Schmidt JA, McCleery R, Seavey JR, Cameron Devitt SE, Schmidt PM (2012) Impacts of a half 700 century of sea-level rise and development on an endangered mammal. Global Change 701 Biology 18: 3536-3542.

702 Shochat E, Warren PS, Faeth SH, McIntyre NE, Hope D (2006) From patterns to emerging 703 processes in mechanistic urban ecology. Trends in Ecology and Evolution 21: 186-191.

704 Schoener TW (1982) The controversy over interspecific competition. American Scientist 70: $705 \quad 586-595$.

706 Schoener TW (1983) Field experiments on interspecific competition. American Naturalist 122: $707 \quad 240-285$.

708 Smirnov PK (1974) Biotopic distribution and territorial relationship of the steppe and Pallas' 709 pika in the sympatric zone of their ranges. Byulleten' Moskovskogo Obshchestva Ispytatelei $710 \quad$ Prirody Otdel Biologicheskii 75: 72-80.

711 Smith AT, Xie Y (2008) A Guide to the Mammals of China. Princeton University Press, 712 Princeton, New Jersey, USA.

713 Smith DF, Litvaitis JA (1999) Differences in eye size and predator-detection distances of New $714 \quad$ England and eastern cottontails. Northeast Wildlife 54: 55-60.

715 Smith DF, Litvaitis JA (2000) Foraging strategies of sympatric lagomorphs: implications for 716 differential success in fragmented landscapes. Canadian Journal of Zoology 78: 2134-2141.

717 Sokolov VE, Ivanitskaya EY, Gruzdev VV, Heptner VG, Hoffmann RS, Smith AT (2009) 718 Lagomorphs: mammals of Russia and adjacent regions. CRC Press, Boca Raton, Florida, $719 \quad$ USA. 
Somers N, Milotic T, Hoffmann M (2012) The impact of sward height, forage quality and competitive conditions on foraging behaviour of free-ranging rabbits (Oryctolagus cuniculus L.). Belgian Journal of Zoology 142: 74-85.

Su JP (2001) A comparative study on the habitat selection of plateau pika (Ochotona curzoniae) and Gansu pika (Ochotona cansus). PhD thesis, Northwest Plateau Institute of Biology, Xining, Qinghai, China.

Tafani M, Cohas A, Bonenfant C, Gaillard J-M, Allainé D (2013) Decreasing litter size of marmots over time: a life history response to climate change? Ecology 94: 580-586.

Thulin C-G (2003) The distribution of mountain hares Lepus timidus in Europe: a challenge from brown hares L.europaeus? Mammal Review 33: 29-42.

Thulin C-G, Tegelström H (2002) Biased geographical distribution of mitochondrial DNA that passed the species barrier from mountain hares to brown hares (genus Lepus): an effect of genetic incompatibility and mating behaviour? Journal of Zoology 258: 299-306.

Tylianakis JM, Didham RK, Bascompte J, Wardle DA (2008) Global change and species interactions in terrestrial ecosystems. Ecology Letters 11: 1351-1363.

Vellend M, Cornwell WK, Magnuson-Ford K, Mooers AO (2011) Chapter 14: Measuring phylogenetic diversity. In: Magurran AE, McGill BJ (eds) 193-206. Biological Diversity: Frontiers in Measurement and Assessment. Oxford University Press, Oxford, UK.

Venail PA, Narwani A, Fritschie K, Alexandrou MA, Oakley TH, Cardinale BJ (2014) The influence of phylogenetic relatedness on species interactions among freshwater green algae in a mesocosm experiment. Journal of Ecology 102: 1288-1299. 
741 Vidus-Rosin A, Gilio N, Meriggi A (2008) Introduced lagomorphs as a threat to 'native' 742 lagomorphs: the case of the Eastern cottontail (Sylvilagus floridanus) in Northern Italy. In: 743 Alves PC, Ferrand N, Hackländer K (eds) Lagomorph Biology: Evolution, Ecology and 744 Conservation, 153-165. Springer-Verlag Berlin Heidelberg.

745 Vidus-Rosin A, Meriggi A, Cardarelli E, Serrano-Perez S, Mariani M-C, Corradelli C, Barba A 746 (2011) Habitat overlap between sympatric European hares (Lepus europaeus) and Eastern

Vidus-Rosin A, Lizier L, Meriggi A, Serrano-Perez S (2012) Habitat selection and segregation by two sympatric lagomorphs: the case of European hares (Lepus europaeus) and Eastern cottontails (Sylvilagus floridanus) in northern Italy. Acta Theriologica 57: 295304.

Violle C, Nemergut DR, Pu Z, Jiang L (2011) Phylogenetic limiting similarity and competitive exclusion. Ecology Letters 14: 782-787.

Watson JEM, Iwamura T, Butt N (2013) Mapping vulnerability and conservation adaptation strategies under climate change. Nature Climate Change 3: 989-994.

Wilson CC, Bernatchez L (1998) The ghost of hybrids past: fixation of arctic charr (Salvelinus alpinus) mitochondrial DNA in an introgressed population of lake trout (S. namaycush). Molecular Ecology 7: 127-132.

Zhang D, Fan N, Yin H (2001) Comparative analysis of behaviour between Ochotona dauurica and Ochotona curzoniae in sympatric coexistence. Journal of Hebei University, Natural Science Edition 21: 72-77. 
763 Table 1. Summary of the 33 competitive interactions documented in the order Lagomorpha,

764 involving 33 species. Type of competitive interaction (exploitation or interference), resource

765 competing for, and a citation for the interaction are also listed. Invasive interactions are

766 highlighted in bold.

\begin{tabular}{|c|c|c|c|c|}
\hline Competition & For... & Species & Replaced by... & Citation \\
\hline Exploitation & Habitat & Brachylagus idahoensis & Lepus californicus & Pierce et al. 2011 \\
\hline Exploitation & Habitat & Brachylagus idahoensis & Sylvilagus audubonii & Pierce et al. 2011 \\
\hline Exploitation & Habitat & Bunolagus monticularis & Lepus capensis & Duthie 1989 \\
\hline Exploitation & Habitat & Lepus alleni & Lepus californicus & Chapman \& Flux 1990 \\
\hline Exploitation & Habitat & Lepus americanus & Lepus townsendii & Leopold 1947 \\
\hline Exploitation & Habitat & Lepus americanus & Sylvilagus nuttallii & Frey \& Malaney 2006 \\
\hline Exploitation & Habitat & Lepus callotis & Lepus californicus & Best \& Henry 1993 \\
\hline Exploitation & Habitat & Lepus capensis & Lepus habessinicus & Flux 2008 \\
\hline Exploitation & Habitat & Lepus capensis & Lepus europaeus & Chapman \& Flux 1990 \\
\hline Exploitation & Habitat & Lepus corsicanus & Lepus europaeus & Angelici et al. 2008 \\
\hline Exploitation & Habitat & Lepus europaeus & Lepus tolai & Sokolov et al. 2009 \\
\hline Exploitation & Habitat & Lepus europaeus & Lepus granatensis & Gortázar et al. 2007 \\
\hline Exploitation & Habitat & Lepus habessinicus & Lepus microtis & Chapman \& Flux 1990 \\
\hline Exploitation & Habitat & Lepus habessinicus & Lepus saxatilis & Chapman \& Flux 1990 \\
\hline Exploitation & Habitat & Lepus habessinicus & Lepus fagani & Chapman \& Flux 1990 \\
\hline Exploitation & Habitat & Lepus mandshuricus & Lepus tolai & $\begin{array}{l}\text { Chapman \& Flux 1990, } \\
\text { Smith \& Xie } 2008\end{array}$ \\
\hline Exploitation & Habitat & Lepus microtis & Lepus saxatilis & Flux 2008 \\
\hline Exploitation & Habitat & Lepus timidus & Lepus europaeus & Thulin 2003, Reid 2011 \\
\hline Exploitation & Habitat & Lepus townsendii & Lepus californicus & Flinders \& Chapman 2003 \\
\hline Exploitation & Habitat & Ochotona cansus & Ochotona curzoniae & Chapman \& Flux 1990 \\
\hline Exploitation & Habitat & Ochotona dauurica & Ochotona curzoniae & Zhang et al. 2001 \\
\hline Exploitation & Habitat & Ochotona koslowi & Ochotona curzoniae & Buchner 1894 \\
\hline Exploitation & Habitat & Ochotona koslowi & Ochotona ladacensis & Buchner 1894 \\
\hline Exploitation & Habitat & Sylvilagus audubonii & Lepus californicus & $\begin{array}{l}\text { AMCELA (Mexican } \\
\text { Association for } \\
\text { Conservation and } \\
\text { Study of Lagomorphs) et al. } \\
2008\end{array}$ \\
\hline Exploitation & Habitat & Sylvilagus audubonii & Lepus callotis & Best \& Henry 1993 \\
\hline Exploitation & Habitat & Sylvilagus brasiliensis & Lepus europaeus & Novillo \& Ojeda 2008 \\
\hline Exploitation & Shelter & Ochotona hyperborea & Ochotona alpina & Chapman \& Flux 1990 \\
\hline Interference & Habitat & Brachylagus idahoensis & Sylvilagus floridanus & Pierce et al. 2011 \\
\hline Interference & Habitat & Ochotona pusilla & Ochotona pallasi & Sokolov et al. 2009 \\
\hline Interference & Habitat & Sylvilagus bachmani & Sylvilagus floridanus & Chapman \& Verts 1969 \\
\hline Interference & Habitat & Sylvilagus brasiliensis & Sylvilagus floridanus & Chapman \& Flux 1990 \\
\hline Interference & Habitat & Sylvilagus nuttallii & Sylvilagus floridanus & Genoways \& Jones 1972 \\
\hline Interference & Habitat/food & Sylvilagus transitionalis & Sylvilagus floridanus & $\begin{array}{l}\text { Probert \& Litvaitis 1996, } \\
\text { Litvaitis et al. } 2008\end{array}$ \\
\hline
\end{tabular}


Fig. 1.

(a)
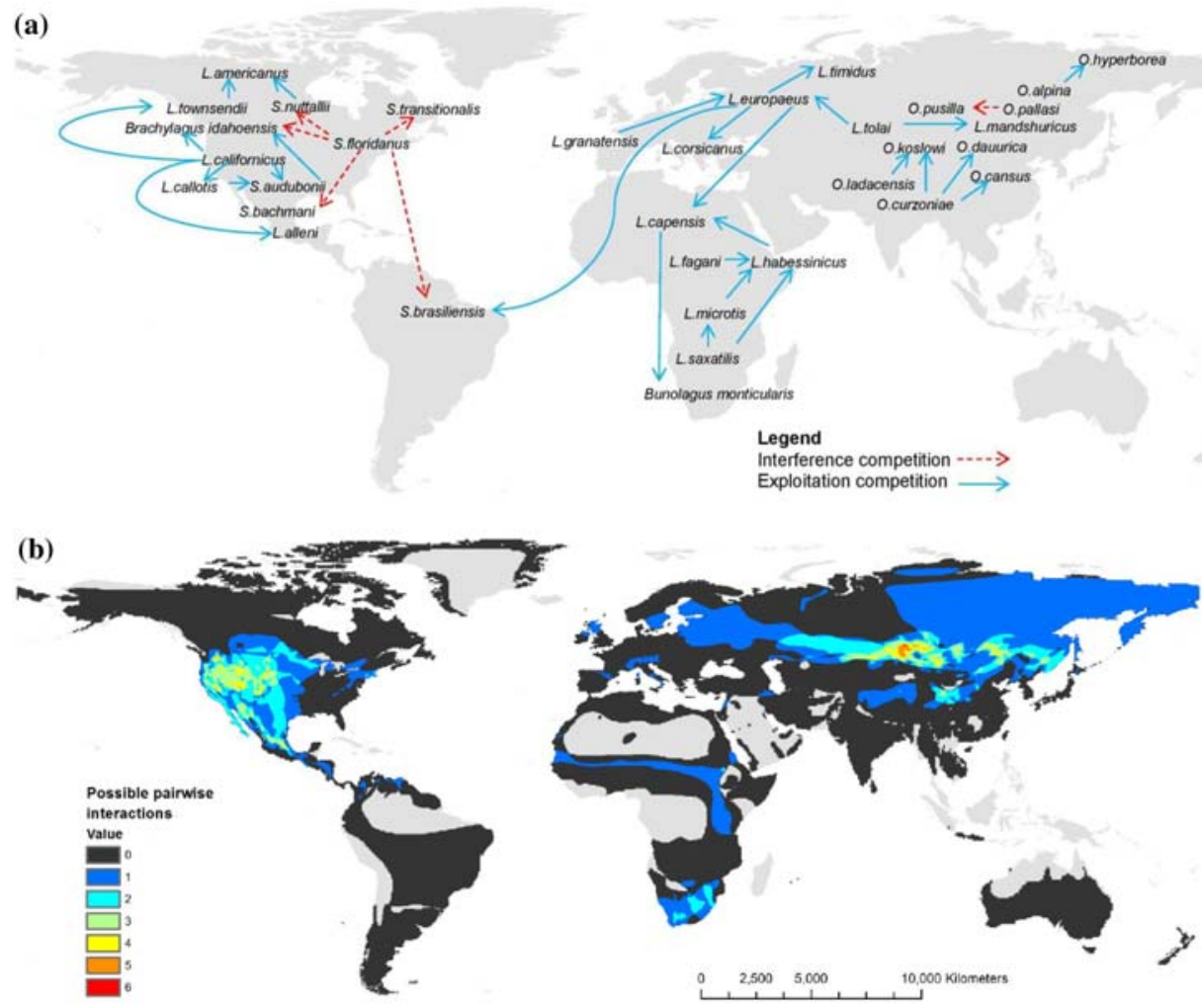

(c)

(d)
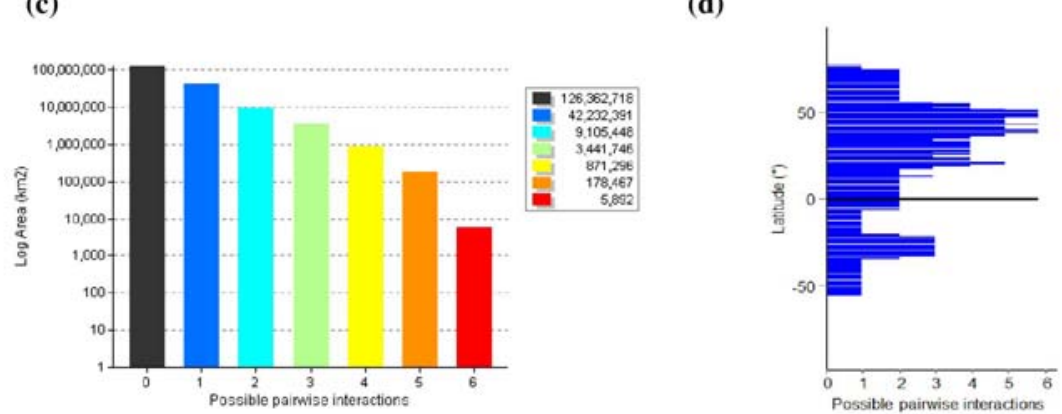

771 Figure 1. (a) Documented competitive interactions in the order Lagomorpha shown in their 772 approximate geographic locations. Red arrows (dashed) indicate interference competition, blue arrows indicate exploitation competition. (b) Global distribution of possible pairwise competitive interactions between the 33 species in the order Lagomorpha that have documented interactions with other species. Pale grey areas indicate places where no lagomorph species are found. (c) Histogram of the area occupied by possible pairwise interactions between species documented to interact with others. (d) Histogram of the latitudes occupied by possible pairwise 
interactions between species known to interact with others; the bold line represents the Equator.

779 In (b), (c) and (d), zero possible pairwise interactions indicates the occurrence of one species not

780 documented to interact with others.

781

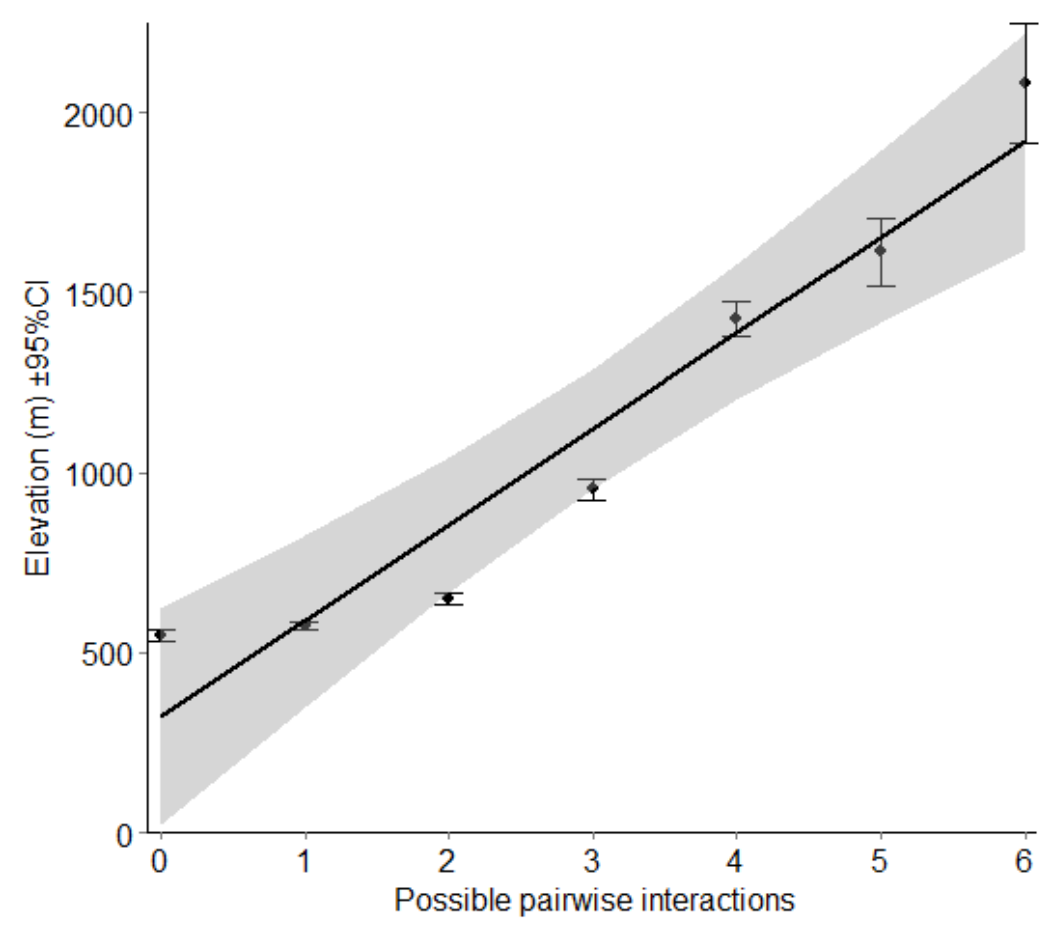

783 Figure 2. Relationship between possible pairwise interactions in species of Lagomorpha

784 documented to interact with others and elevation $(\mathrm{m})$, with $\pm 95 \%$ confidence error bars. The

785 grey area surrounding the fitted linear regression line indicates the $95 \%$ confidence limits. 
Fig. 3.
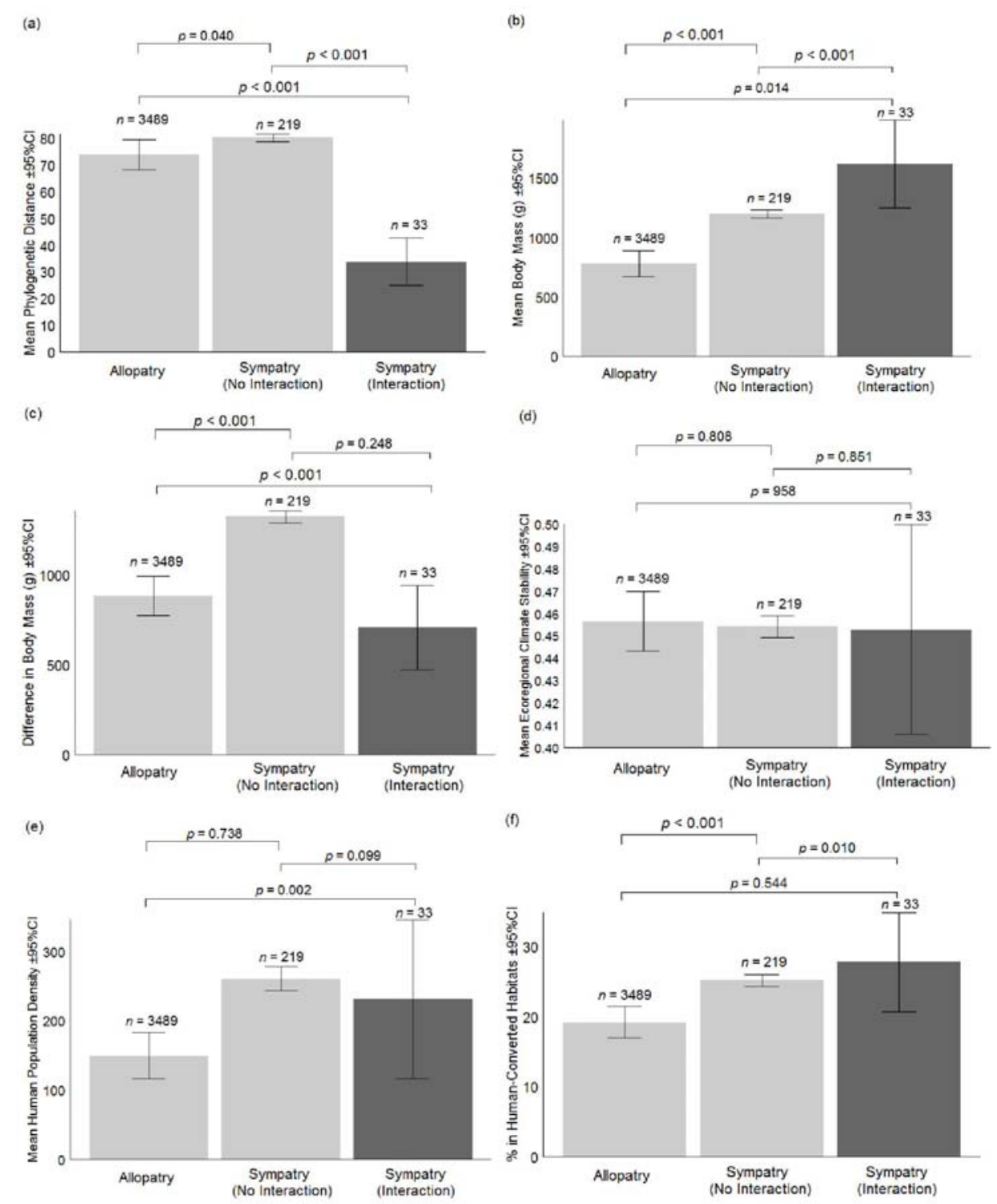

787 Figure 3. Mean phylogenetic distance (a), mean body mass (b), difference in body mass 788 between each species in an interacting pair (c), mean ecoregional climate stability (d), mean 789 human population density (e) and mean percentage of occurrence records in human-converted 790 habitats (f) $\pm 95 \%$ confidence intervals, for lagomorph species in allopatry (light grey), sympatry 791 with no known interaction (light grey) and sympatry with an interaction (dark grey). 
794 Appendix S1. Variables considered, but not included in the analysis.

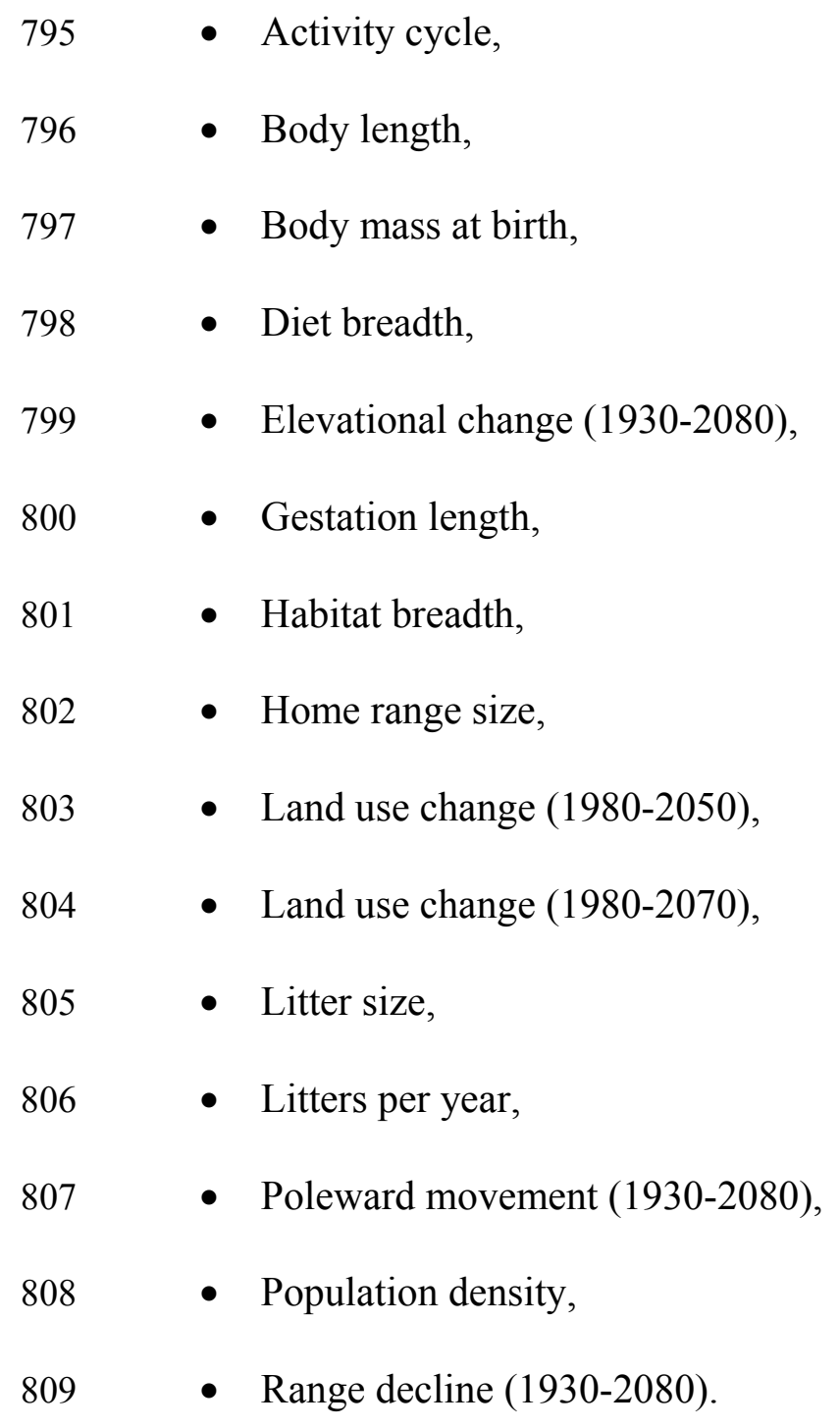


811 Appendix S2. Results of Generalized Linear Models characterising phylogenetic distance, body

812 mass, difference in body mass, ecoregional climatic stability, human population density and

813 percentage of occurrence records in human-converted habitats for pairs of species of lagomorph

814 in allopatry, sympatry with no interaction and sympatry with an interaction. Significant $p$ values

815 are in bold.

\begin{tabular}{|c|c|c|c|c|}
\hline Response variable & Term & $\beta \pm$ s.e. & $t$ & $p$ \\
\hline \multirow[t]{3}{*}{$\begin{array}{l}\text { Mean phylogenetic distance } \\
F_{2,3738}=19.80(p<0.001)\end{array}$} & $\begin{array}{l}\text { Sympatry-Interaction \& Sympatry- } \\
\text { No Interaction }\end{array}$ & $39.971 \pm 7.791$ & 5.130 & $<0.001$ \\
\hline & Sympatry-Interaction \& Allopatry & $-46.311 \pm 7.729$ & -5.992 & $<0.001$ \\
\hline & $\begin{array}{l}\text { Sympatry-No Interaction \& } \\
\text { Allopatry }\end{array}$ & $-6.340 \pm 3.078$ & -2.060 & 0.040 \\
\hline \multirow[t]{3}{*}{$\begin{array}{l}\text { Mean adult body mass }(\mathrm{g}) \\
F_{2,3738}=22.26(p<0.001)\end{array}$} & $\begin{array}{l}\text { Sympatry-Interaction \& Sympatry- } \\
\text { No Interaction }\end{array}$ & $-838.100 \pm 162.500$ & -5.159 & $<0.001$ \\
\hline & Sympatry-Interaction \& Allopatry & $419.790 \pm 170.930$ & 2.456 & 0.014 \\
\hline & $\begin{array}{l}\text { Sympatry-No Interaction \& } \\
\text { Allopatry }\end{array}$ & $-418.300 \pm 68.080$ & -6.144 & $<0.001$ \\
\hline \multirow[t]{3}{*}{$\begin{array}{l}\text { Difference in adult body mass ( } \mathrm{g}) \\
F_{2,3738}=26.81(p<0.001)\end{array}$} & $\begin{array}{l}\text { Sympatry-Interaction \& Sympatry- } \\
\text { No Interaction }\end{array}$ & $176.100 \pm 152.000$ & 1.159 & 0.248 \\
\hline & Sympatry-Interaction \& Allopatry & $-616.590 \pm 171.230$ & -3.601 & $<0.001$ \\
\hline & $\begin{array}{l}\text { Sympatry-No Interaction \& } \\
\text { Allopatry }\end{array}$ & $-440.470 \pm 68.200$ & -6.458 & $<0.001$ \\
\hline \multirow[t]{3}{*}{$\begin{array}{l}\text { Mean ecoregional climate stability } \\
F_{2,3738}=0.03(p=0.969)\end{array}$} & $\begin{array}{l}\text { Sympatry-Interaction \& Sympatry- } \\
\text { No Interaction }\end{array}$ & $0.004 \pm 0.020$ & 0.188 & 0.851 \\
\hline & Sympatry-Interaction \& Allopatry & $-0.001 \pm 0.025$ & -0.053 & 0.958 \\
\hline & $\begin{array}{l}\text { Sympatry-No Interaction \& } \\
\text { Allopatry }\end{array}$ & $0.002 \pm 0.010$ & 0.243 & 0.808 \\
\hline \multirow[t]{3}{*}{$\begin{array}{l}\text { Mean human population density } \\
F_{2,3738}=5.02(p<0.001)\end{array}$} & $\begin{array}{l}\text { Sympatry-Interaction \& Sympatry- } \\
\text { No Interaction }\end{array}$ & $-81.760 \pm 49.480$ & -1.653 & 0.099 \\
\hline & Sympatry-Interaction \& Allopatry & $-29.580 \pm 88.508$ & -0.334 & 0.738 \\
\hline & $\begin{array}{l}\text { Sympatry-No Interaction \& } \\
\text { Allopatry }\end{array}$ & $-111.342 \pm 35.253$ & -3.158 & 0.002 \\
\hline \multirow{3}{*}{$\begin{array}{l}\text { Mean \% of occurrence records in human- } \\
\text { converted habitats } \\
F_{2,3738}=6.30(p=0.002)\end{array}$} & $\begin{array}{l}\text { Sympatry-Interaction \& Sympatry- } \\
\text { No Interaction }\end{array}$ & $-8.538 \pm 3.269$ & -2.612 & 0.010 \\
\hline & Sympatry-Interaction \& Allopatry & $2.600 \pm 4.283$ & 0.607 & 0.544 \\
\hline & $\begin{array}{l}\text { Sympatry-No Interaction \& } \\
\text { Allopatry }\end{array}$ & $-5.940 \pm 1.706$ & -3.482 & $<0.001$ \\
\hline
\end{tabular}

